\title{
Good Governance and Pro-Active Implementation of Corporate Social Responsibility in Indonesia
}

\author{
Martono Anggusti \\ Universitas Sumatera Utara \\ Medan, Indonesia \\ martono.pang@gmail.com
}

\begin{abstract}
The measure of a Company's success should be determined by not only reporting a profit, but also by its Corporate Social Responsibility (CSR) implementation, such as good governance, social responsibility, ethical behavior, environmental initiatives, and ways of creating long term sustainable development. CSR is a concept that all entities themselves must conduct responsibly, with consideration for the communities they operate in. It encourages companies to transition from the mandatory usual business practice to corporate citizenship with the right to "do good and do no harm." As problems with economic inequality are unresolved, how does mandatory CSR allow more pro-active implementation by corporate to solve the inequality and economic gap? How can governance help in assembling CSR programs that could improve existing situation to achieve national development goals?
\end{abstract}

Keywords: Good Governance, Stakeholders, Corporate Social Responsibility, Sustainable Development.

\section{INTRODUCTION}

From the principle of the state economy in accordance with the 1945 Constitution stated that: "Later than it was to form a Government of the State of Indonesia which protect the entire Indonesian nation and the entire homeland of Indonesia and to promote the general welfare, nationwide education system, ......."

When searching the 1945 Constitution, it can be concluded that the company did not have an interest in dealing with the country's obligations have been clearly established in law.
But still the Indonesian government has enacted nine regulations related to corporate social responsibility to encumber the companies. Company Limited Act No.40/2007 has changed the paradigm of CSR generosity of nature (charity) becomes a legal obligation or mandatory. However, the problems again occur when, Article 4 paragraph (1) of Government Regulation No. 47/2012, stated that, Social and Environmental Responsibility (TJSL) or CSR implemented by company directors based on the annual work plan approved in Annual General Meeting of Shareholders (AGM). Meaning, Article 4 paragraph (1) states that CSR is not mandatory, subject to AGM's decision. This article also completely disarm state power to compel a company which does not incorporate CSR budget in financial planning. This will potentially be an additional justification tool for managers and owners of corporations that have been reluctant to carry out their social obligations.

Furthermore, The Social Ministerial Decree RI No. 185 / HUK / 2016 on forums liable entities in the implementation of social welfare stated: Forming Forum social responsibility of legal entities in the implementation of social welfare consists of, National Supervisors (Minister of Social Affairs, Director General of Social Empowerment, Society, Enterprises and Universities); Inspectors (Director of Social Empowerment Individual, Family and Community Institutional, Deputy Director of the Business Potential, members) and Administrator Of The National level and the national level valid for a term 
of five years until 2020. Administrators Forum National Level: (1) Chairman, (2) Chairman I (of Organization and Institutional), (3) Chairman II (Field Data, Information Communication), (4) Chairman III (Field Socialization and Partnership), (5 ) Secretary, (6) Deputy Secretary, (7) Treasurer, (8) Deputy Treasurer, (9) Regional Coordinator (Regional I: Sumatra; Regional II: Kalimantan: Regional III: Sulawesi, Maluku and Papua, Regional IV: Java, Bali and Nusa Tenggara). This forum is not effective and efficient, should the centre consists of, Minister of Social Affairs, the Director General of Social Empowerment, Enterprises and Society, as well as in the provinces, districts / cities consist of regional coordinators shaped, Regional I, II, III, IV, where the structure consists of governments, businesses, communities and colleges.

Minister of Social Affairs Regulation No. 6 Year 2016 About Social Responsibility Enterprises in the Implementation of Social Welfare. Article 1 paragraph 2 stated that Enterprises are juridical and economic unity of the factors of production that aims for profit. It means for all companies. The Regulation No. 6 Year 2016 created confusion when seen in Article 74 (1) The Company is conducting its business activities only in the field and / or related to the natural resources required to implement the Social and Environmental Responsibility. This mean not all companies.

Employers can no longer avoid the issue of ethics in business. To encourage ethical behaviour in the workplace, many companies establish a code of ethics (code of conduct) and set a clear ethical position to run a business. The topics covered by the company's code of ethics and standards of conduct, as follows: (1) Fundamental Honesty and Adherence to the Law;(2) Product safety in the workplace;(3) Conflict of interest;(4) Employment Practices;(5) Fairness in selling/marketing Practices;(6) Financial Reporting;(7) Supplier Relationships;(8) Pricing, Billing, and Contracting;(9) Trading in Securities/Using Inside Information;(10) Payments to Obtain Business/Foreign Corrupt Practices Act;(12) Acquiring and Using Information about Others;(13) Security;(14) Political Activities... etc.

Corporate Social Responsiveness (corporate social sensitivity) is a theory of social responsibility that focuses on how companies should respond to the problem, and instead of trying to determine which is the main social responsibility. In individual companies, managers trying to implement the principles of the social contract in various decision-making processes and in their company policy. Decisions and policies they can reflect one of four establishments, namely: (1) Reactive - companies responding on social issues only after the issues that jeopardize the company's goals;(2) Defensive - companies act to deflect challenges that occur;(3) Accommodative the company conform to the requirements of the government and public opinion;(4) Proactive - Companies anticipate the demands that have not been made.

At this time many companies become more developed, it was then that the social gap and damage the surrounding environment can occur, because it appears the awareness to mitigate this negative impact. Many private companies are now developing what is called Corporate Social Responsibility (CSR). CSR is no longer just viewed from a single bottom line, see the company's financial condition but also views of the triple bottom line. Bottom line not only in financial terms but also from a social and environmental.

To fulfil its social contract society, companies are faced with several social responsibility simultaneously. Corporate social responsibility (CSR) is one among several corporate responsibility to stakeholders. Stakeholders in this case is the person or group who can affect or be affected by the decisions, policies and operations of the company. Namely: Internal stakeholders (Employees, Manager, owners ...) and External stakeholders (suppliers, society, government, creditors, shareholders, customers...).

The results of the interviews generate the most significant issue gets the attention of experts CSR so worthy to note the company in running its CSR activities, as follows:(1) Environmental Issues and Climate Change;(2) Transparency and Accountability;(3) Institutionalization of CSR;(4) Engagement with Stakeholders;(5) Labour rights as Human Rights;(6) Investment in the Community;(7) Supply Chain and Product Safety;(8) Social Enterprises;(9) Poverty Reduction;(10) Seizing Talented Labour;(11) Law enforcement.

Length of vision planning should not be too long ahead, 
ideally about three years. Else, it would be hard to imagine the business landscape in longer timeframe. Visioning starts with the analysis Threat and Opportunity earlier so that we continue to be alert.

Table 1. Decision Making Model

\begin{tabular}{|c|c|}
\hline $\begin{array}{c}\text { STAGE } \\
\text { PROCESS }\end{array}$ & EXPLANATION \\
\hline $\begin{array}{l}\text { INVESTIGA } \\
\text { TION }\end{array}$ & $\begin{array}{l}\text { Study the environment on a condition that requires a } \\
\text { decision. The raw data was obtained, processed and } \\
\text { tested for clues that can identify problems. }\end{array}$ \\
\hline PLANNING & $\begin{array}{l}\text { Registering, developing, and analyzing possible } \\
\text { courses of action. This includes processes to } \\
\text { understand the problem, resulting in the } \\
\text { breakdown, and test the feasibility of solving. }\end{array}$ \\
\hline SELECTION & $\begin{array}{l}\text { Selecting the direction of action of all that exists. } \\
\text { The choice is determined and implemented. }\end{array}$ \\
\hline
\end{tabular}

According to ISO 26000 there are six stages that must be met in teamwork:(1) The Current Picture;(2) Evaluation on seven core subjects;(3) Involve stakeholders (Engaging your stakeholders) ;(4) Plan to progress (Plans for Improvement);(5) Public Reporting;(6) Claiming Credit.

Flow Chart of Good Governance and Pro-Active Implementation of Corporate Social Responsibility (CSR) in Indonesia.

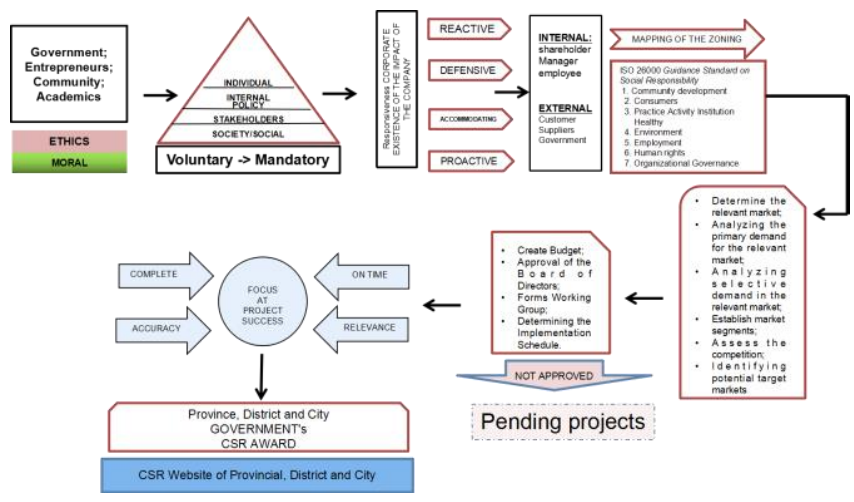

\section{CONCLUSIONS AND RECOMMENDATIONS}

Companies around the world have created their own CSR aims to balance their operations with concern for the external and internal stakeholders. Effective good governance CSR program starts at the top of the organization with the commitment of the board of directors and senior officers. The good governance CSR program is designed to minimize the conflict between the company and stakeholders. Most companies issue reports CSR / sustainability on an annual basis, which allows them to integrate reporting / CSR sustainability joint annual financial reporting process. CSR Report on social performance is the key to build stakeholder trust and support of the goals and achievements of social progress. Effective CSR programs requires a good governance organization to provide the society, above and beyond their own interests and legal obligations. A way for companies to be ethical is to consider the welfare of the workforce, society, the environment, in addition to profits.

CSR settings on Law No.40 / 2007 has been quite good. Which needs to include in the Government Regulation No. 47/2012 are:

1. The value of CSR imposed on the Company that the company should divided into two categories, namely: (1). The Company is conducting its business activities in the field and / or related to natural resources, is calculated at $0.5 \%$ of nett sale base, and (2) the Company beyond of the paragraph (1), subject to $1,5 \%-2 \%$ of company nett profit.

2. The role of government is as: (1) Initiator of the campaign "CARES", (2) Coordinator in mapping problem, (3) Regulator, as a party to the team, along with businesses, communities and universities, (4) The catalyst, Motivator and a dynamic. The role of the business world as an executor, problem solving and participated in the team formed with government regulations, a team of experts from the university and the community. Society as a beneficiary providing input matters and participated in the team formed with government regulations, a team of experts and the business world. Expert team (universities) to support, guides so that CSR can be done well.

3. Governance is mainly concerned with the Human Resources working in the System. Good person leads to Good Institution; Good Institution leads to Good Governance; Good Governance leads to stronger governance.

4. Good governance in the context of sustainable development in Indonesia can be seen as a synergistic effort that combines environmental development, human (leading by example) and economic (with principle of togetherness - cooperative - kinship), and that should be done simultaneously. The three actors in implementing the principles for sustainable development are government, corporations, and educated civil society who are able to maintain and participate processes being performed. Good governance will then serve as an element that 
Advances in Social Science, Education and Humanities Research, volume 84

combines three of the actors in one container for the same purpose. Without good governance will be difficult for each side to be able to contribute to each other and watch each other. Further, in view of the sustainability of existing sustainable development, namely environmental sustainability, economic, and human development, good governance established itself as a slice to synergistically bring together three links for sustainability. With good governance, the consistent achievement of sustainability can be measured in accordance with the principles of good governance that has been said previously. Good governance provides a space for each stakeholder to complement each other and have a control function between one and the other.

5. Mapping The Zoning of the CSR needs where the companies exist.

6. Updated Data at the government website publishing the finished projects done.

7. Reward and Recognition to the Companies from the Government.

8. Judicial Review for the Sanction in the Government Regulation No. 47/2012 as stated in Limited Liability Company Act No.40/2007, article 74

paragraph (3) Companies who do not put their obligation into practice as contemplated in paragraph (1) shall be liable to sanctions in accordance with the provisions of legislative regulations. (4) Further provisions regarding Environmental and Social Responsibility shall be stipulated by Government Regulation.

9. Built CSR programs in the Principal of mutual beneficial, and in the long term cooperation between the parties.

10. A Clear Division of the responsibilities of the government project and non-governmental.

\section{REFERENCES}

Agus Arijanto, “Etika Bisnis bagi Pelaku Bisnis,” Jakarta: Rajagrafindo Persada, 2011

Amin Wijaya Tunggal, Pengantar Business Ethics dan Corporate Social Responsibility (CSR), Harvarindo, 2013.

Ann Brockett, Zabihollah Rezaee.(2012). Corporate Sustainability, Integrating Performance and Reporting, Canada: John Wiley \& Sons, Inc.

Freeman R.E., Strategic Management: a stakeholder Approach, Marchfield, MA, Pitman, 1984.

Gregorius Chandra, Strategi dan Program Pemasaran, Yogyakarta: Andi
Offset, 2005

Hermawan Kartajaya, New Wave Marketing, The World is Still Round The Market is Already Flat, Jakarta: PT.Gramedia Pustaka Utama, 2010. Ismail Solihin, Manajemen Strategik, Bandung: Penerbit Erlangga. http://asq.org/learn-about-quality/learn-about-standards/iso-26000/, 2012 Kenneth C.Laudon, Jane P.Laudon, Management Information Systems, Managing the Digital Firm, Fourteenth Edition, England: Pearson Education Limited, 2016.

Martono Anggusti, Tanggung Jawab Sosial Perusahaan, Bandung: Books Terrace \& Library, 2010.

Philip, Kotler and Nancy Lee. Corporate Social Responsibility, New Jersey: John Wiley \& Sons, Inc, 2005

Raymond Mc Leod,Jr, George P. Schell. Sistem Informasi Manajemen, Edisi 10, Jakarta: Salemba, 2008.

Rohmat Taufiq. Sistem Informasi Manajemen, Yogyakarta: Graha Ilmu, 2013

Sedarmayanti, Good Governance. Kepemerintahan Yang Baik dan Good Corporate Governance, Tata Kelola Perusahaan Yang Baik, Bandung: Penerbit Mandar Maju, 2007.

Siswanto Sutojo, E John Aldridge, Tata Kelola Perusahaan Yang Sehat. Jakarta: PT Damar Mulia Pustaka, 2005.

Sofjan Assauri, Manajemen Pemasaran, Jakarta: PT.Raja Grafindo Persada, 2010

Sukaria Sinurlingga, Analisis Lingkungan Usaha, Medan: Usu Press, 2007.

Susanto A,B, . A Strategic Management Approach CSR, Jakarta: Mitra Satya, 2007

Thomas L. Wheelen, J.David Hunger, et all. Strategic Management and Business Policy, Globalization, Innovation, and Sustainability, Fouteenth Edition, England: Pearson Education Limited, 2015.

Untung Budi Hendrik, Corporate Social Responsibility, Jakarta: Sinar Grafika, 2008

Yusuf Wibisono, Membedah Konsep \& Aplikasi CSR, Gresik:Fasco Publishing, 2007.

Zulkarnain Lubis, Koperasi Untuk Ekonomi Rakyat ,Bandung: Citapustaka

Media Perintis, 2008.

UU No.40 Tahun 2007 Tentang Perseroan Terbatas

UU No.25 Tahun 2007 Tentang Penanaman Modal

UU No. 22 Tahun 2001 Tentang Minyak dan Gas Bum

UU No. 13 Tahun 2011 Tentang Penangan Fakir Miskin

UU No. 4 Tahun 2009 Tentang Pertambangan Mineral dan Batu bara

UU No. 11 Tahun 2011 Tentang Kesejahteraan Sosial

Peraturan Menteri Sosial RI Nomor. 6 Tahun 2016 Tentang Tanggung Jawab Sosial Badan Usaha Dalam Penyelenggaraan Kesejahteraan Sosial.

Keputusan Menteri Sosial RI Nomor. 185/HUK/2016 Tentang Forum Tanggung Jawab Sosial Badan Usaha Dalam Penyelenggaraan Kesejahteraan Sosial. 
Advances in Social Science, Education and Humanities Research, volume 84

Peraturan Pemerintah Republik Indonesia Nomor 47 Tahun 2012 Tentang

Tanggung Jawab Sosial Dan Lingkungan Perseroan Terbatas.

Permenneg BUMN No. PER-05/MBU/2007, Salinan Permen BUMN No.

PER-20/MBU/2012.

Salinan Permen BUMN No.PER-08/MBU/2013 Tentang Perubahan

Keempat atas Permenneg BUMN.

Permensos No.13 Tahun 2012 Tentang Forum Tanggung-jawab Sunia

Usaha Dalam Penyelenggaraan Keejahteraan Sosial. 